\title{
AN ANALYTICAL STUDY OF EFFECT OF MASS MEDIA IN PROMOTION OF SPORTS IN JAMMU \& KASHMIR
}

\author{
D.O.I - 10.51201/Jusst12659
}

http://doi.org/10.51201/Jusst12659

\section{${ }^{1}$ Dr.Rajwinder Pal Singh, ${ }^{2}$ Ritesh Sharma}

\author{
${ }^{1}$ Asst. Prof, Guru KanshiUni, TalwandiSabho, \\ Bathinda. \\ ${ }^{2}$ Research Scholar, Guru KanshiUni, \\ TalwandiSabho, Bathinda.
}

\begin{abstract}
In the present study, descriptive and survey method was used. The study is the effect of mass media in promotion of sports in Jammu Kashmir. The survey type study was designed to find out the role of media in sports. For measuring selected variables of the study, four different inventories/tests were administered to the subject of the study. Here all these variables were independent variables. The populations for this research are selected from Jammu \& Kashmir state. The primary sources of data were sportsmen. The selected NineUniversities from Jammu \& Kashmir state.From the above question regarding the Participate in Physical Activities Regularly, it is observed that: $84.32 \%$ Say Yes, $14.90 \%$ Say Sometime and 1.6\% Say No Participate in Physical Activities Regularly.From the above question regarding the Mass Media Provide You with Adequate Information about Sport Benefits it is observed that: $86.91 \%$ Say Yes, $12.39 \%$ Say Sometime and $0.7 \%$ Say No mass media provide you with adequate information about sport benefits.From the above question regarding the Mass Media Play a Role in The Dissemination of Sport Benefits for Good Health, It is observed that: 67.63\%Say Yes, 31.37\%Say Sometime and $1.2 \%$ Say No mass media play a role in the dissemination of sport benefits for good health.From the above question regarding the Mass Media Show an Interest in Health Benefits of Sport, it is observed that: 82.32\%Say Yes, 15.78\%Say Sometime and 1.9\%Say No Mass Media Show an Interest in Health Benefits of Sport.From the above question regarding the Mass Media Encourage and Cover Sport Activities for Good Health, it is observed that: $85.31 \%$ Say Yes, $12.99 \%$ Say Sometime and $1.7 \%$ Say No mass media encourage and cover sport activities for good health.From the above question regarding the Mass Media Have an Influence on the Public to Participate in Sport Activities, it is observed that: 86.91\%Say Yes, 12.39\%Say Sometime and 0.7\% Say No mass media have an influence on the public to participate in sport activities. From the above question regarding the Mass Media Your Only Source to Get Information About Sports, it is observed that: 67.43\%Say Yes, 31.37\%Say Sometime and 1.2\%Say No mass media your only source to get information about sports.From the above question regarding the Mass Media Use Distinguished Sports Persons to Encourage Others to Participate in Sport, it is observed that: $80.72 \%$ Say Yes, 15.68\% Say Sometime and 3.6\%Say No mass media use distinguished sports persons to encourage others to participate in sport.From the above question regarding the Mass Media Have a Role to Encourage Participation in Sports Activities in Order to Improve Health, it is observed that:
\end{abstract}


82.32\% Say Yes, $15.78 \%$ Say Sometime and 1.9\% Say No mass media have a role to encourage participation in sports activities in order to improve health.

\section{Keywords: -Mass Media, Sports, Sport Activities.}

\section{INTRODUCTION}

Sport is generally recognized as activities that are based on physical athleticism or physical dexterity. Several competitive, but non-physical, activities claim recognition as mind sports. The International Olympic Committee (through ARISF) recognizes both chess and bridge as bona fide sports and Sport Accord, the international sports federation association, recognizes five nonphysical sports although limits the number of mind games that can be admitted as sports. Sports are usually governed by a set of rules or customs, which serve to ensure fair competition[1]. Winning can be determined by physical events such as scoring goals or crossing a line first, or by the determination of judges who are scoring elements of the sporting performance, including objective or subjective measures such as technical performance or artistic impression. In organized sport, records of performance are often kept and for popular sports, this information may be widely announced or reported in sports news[2]. Besides, sport is a major source of entertainment for nonparticipants. According to A.T. Kearney, a consultancy, the global sporting industry is worth upto \$ 620 billion as of 2013. Broadcasting is the distribution of audio and/.or video content to a dispersed audience via any electronic mass communications medium. The term 'broadcasting' derived from the method of sowing seeds in a field by casting them broadly about, was originated in the early days of radio to distinguish radio broadcasting from methods using the wired transmission (as in telegraph and telephone) or that were intended as person-to-person communication. Broadcasting is usually associated with radio and television [1,3]. The receiving parties may include the general public or a relatively small subset; the point is that anyone with the appropriate receiving technology can receive the signal. The field of broadcasting includes a wide range of practices such as public radio, community radio, and commercial radio, public television, and commercial television $[2,4]$. Transmission of radio and television programs from a radio or television station to home receivers is transmitted using a combination of satellite and wired transmission like cable television are also considered broadcasts and do not require a license. Transmissions of television and radio through digital technology have increasingly been referred to as broadcasting as well, though strictly speaking this is incorrect [5]. During the past years, we have seen an increasing involvement of social media in sports.

\section{PROCEDURE}

In the present study, descriptive and survey method was used. The study is the effect of mass media in promotion of sports in Jammu Kashmir. The survey type study was designed to find out the role of media in sports. For measuring selected variables of the study, four different inventories/tests were administered to the subject of the study. Here all these variables were independent variables. The populations for this research are selected from Jammu \& Kashmir state. The primary sources of data were sportsmen. The selected Nine Universities from Jammu \& Kashmir state.

\section{Results}

The statistical treatment was done on the organized data by applying the percentage with respect to each question and the same was critically analyzed for interpretation of results 
Objective no 1. The role of mass media encouraging the participation in sport activities.

\subsection{Tables}

Physical Activities Regularly.

\begin{tabular}{|l|l|l|}
\hline Responses & $\begin{array}{l}\text { Q1: Do you participate in physical } \\
\text { activities regularly? }\end{array}$ & Percentage \\
\hline YesN(\%) & 844 & $84.32 \%$ \\
\hline SometimesN(\%) & 141 & $14.90 \%$ \\
\hline NoN(\%) & 16 & $1.6 \%$ \\
\hline
\end{tabular}

From the above question regarding the Participate in Physical Activities Regularly, it is observed that:

84.32\% Say Yes totheParticipate in Physical Activities Regularly.

14.90\% Say Sometime Participate in Physical Activities Regularly.

1.6\% Say No Participate in Physical Activities Regularly.

\subsection{Tables}

Mass Media Provide You with Adequate Information About Sport Benefits.

\begin{tabular}{|l|l|l|}
\hline \multicolumn{1}{|c|}{ Responses } & $\begin{array}{l}\text { Q2: Does mass media provide you with adequate } \\
\text { information about sport benefits? }\end{array}$ & Percentage \\
\hline $\begin{array}{l}\text { Yes } \\
\mathrm{N}(\%)\end{array}$ & 870 & $86.91 \%$ \\
\hline $\begin{array}{l}\text { Sometimes } \\
\mathrm{N}(\%)\end{array}$ & 124 & $12.39 \%$ \\
\hline $\begin{array}{l}\mathrm{No} \\
\mathrm{N}(\%)\end{array}$ & 7 & $0.7 \%$ \\
\hline
\end{tabular}

From the above question regarding the Mass Media Provide You with Adequate Information about Sport Benefit observed that:

$86.91 \%$ Say Yes to Themass media provide you with adequate information about sport benefits.

$12.39 \%$ Say Sometime mass media provide you with adequate information about sport benefits.

$0.7 \%$ Say No mass media provide you with adequate information about sport benefits. 


\subsection{Tables}

Mass Media Play a Role in The Dissemination of Sport Benefits for Good Health.

\begin{tabular}{|l|l|l|}
\hline Responses & $\begin{array}{l}\text { Q3: Does mass media play a role in the dissemination of } \\
\text { sport benefits for good health? }\end{array}$ & Percentage \\
\hline $\begin{array}{l}\text { Yes } \\
\mathrm{N}(\%)\end{array}$ & 675 & $67.63 \%$ \\
\hline $\begin{array}{l}\text { Sometimes } \\
\mathrm{N}(\%)\end{array}$ & 314 & $31.37 \%$ \\
\hline $\begin{array}{l}\text { No } \\
\mathrm{N}(\%)\end{array}$ & 12 & $1.2 \%$ \\
\hline
\end{tabular}

From the above question regarding the Mass Media Play a Role in The Dissemination of Sport Benefits for Good Health, it isobserved that:

$67.63 \%$ Say Yes to The mass media play a role in the dissemination of sport benefits for good health.

31.37\% Say Sometime mass media play a role in the dissemination of sport benefits for good health.

1.2\% Say No mass media play a role in the dissemination of sport benefits for good health.

\subsection{Tables}

Mass Media Show an Interest in Health Benefits of Sport.

\begin{tabular}{|l|l|l|}
\hline Responses & $\begin{array}{l}\text { Q4: Does mass media show an interest in health } \\
\text { benefits of sport? }\end{array}$ & Percentage \\
\hline $\begin{array}{l}\text { Yes } \\
\mathrm{N}(\%)\end{array}$ & 824 & $82.32 \%$ \\
\hline $\begin{array}{l}\text { Sometimes } \\
\mathrm{N}(\%)\end{array}$ & 158 & $15.78 \%$ \\
\hline $\begin{array}{l}\text { No } \\
\mathrm{N}(\%)\end{array}$ & 19 & $1.9 \%$ \\
\hline
\end{tabular}


From the above question regarding the Mass Media Show an Interest in Health Benefits of Sport, it is observed that:

82.32\% Say Yes to The Mass Media Show an Interest in Health Benefits of Sport.

15.78\% Say Sometime Mass Media Show an Interest in Health Benefits of Sport.

1.9\% Say No Mass Media Show an Interest in Health Benefits of Sport.

\subsection{Tables}

Mass Media Encourage and Cover Sport Activities for Good Health.

\begin{tabular}{|l|l|l|}
\hline Responses & $\begin{array}{l}\text { Q5: Does mass media encourage and cover sport activities } \\
\text { for good health? }\end{array}$ & Percentage \\
\hline $\begin{array}{l}\text { Yes }(\%) \\
\text { Sometimes }\end{array}$ & 854 & $85.31 \%$ \\
$\mathrm{~N}(\%)$ & 130 & $12.99 \%$ \\
\hline $\begin{array}{l}\text { No } \\
\mathrm{N}(\%)\end{array}$ & 17 & $1.7 \%$ \\
\hline
\end{tabular}

From the above question regarding the Mass Media Encourage and Cover Sport Activities for Good Health, it is observed that:

85.31\% Say Yes to The mass media encourage and cover sport activities for good health.

12.99\% Say Sometime mass media encourage and cover sport activities for good health.

$1.7 \%$ Say No mass media encourage and cover sport activities for good health. 


\subsection{Tables}

Mass Media Have an Influence On the Public to Participate in Sport Activities.

\begin{tabular}{|l|l|l|}
\hline Responses & $\begin{array}{l}\text { Q6: Does mass media have an influence on the public to } \\
\text { participate in sport activities? }\end{array}$ & Percentage \\
\hline $\begin{array}{l}\text { Yes } \\
\mathrm{N}(\%)\end{array}$ & 870 & $86.91 \%$ \\
\hline $\begin{array}{l}\text { Sometimes } \\
\mathrm{N}(\%)\end{array}$ & 124 & $12.39 \%$ \\
\hline
\end{tabular}

From the above question regarding the Mass Media Have an Influence on the Public to Participate in Sport Activities, it is observed that:

86.91\% Say Yes To The mass media have an influence on the public to participate in sport activities.

$12.39 \%$ Say Sometime mass media have an influence on the public to participate in sport activities.

$0.7 \%$ Say No mass media have an influence on the public to participate in sport activities.

\subsection{Tables}

Mass Media Your Only Source to Get Information About Sports.

\begin{tabular}{|l|l|l|}
\hline Responses & $\begin{array}{l}\text { Q7: Is mass media your only source to get information } \\
\text { about sports }\end{array}$ & Percentage \\
\hline $\begin{array}{l}\text { Yes }(\%) \\
\text { Sometimes } \\
\mathrm{N}(\%)\end{array}$ & 675 & $67.43 \%$ \\
\hline $\begin{array}{l}\text { No } \\
\mathrm{N}(\%)\end{array}$ & 12 & $31.37 \%$ \\
\hline
\end{tabular}

From the above question regarding the Mass Media Your Only Source to Get Information About Sports, it is observed that:

$67.43 \%$ Say Yes to The mass media your only source to get information about sports

$31.37 \%$ Say Sometime mass media your only source to get information about sports

$1.2 \%$ Say No mass media your only source to get information about sports 


\subsection{Tables}

Mass Media Use Distinguished Sports Persons to Encourage Others to Participate in Sport.

\begin{tabular}{|l|l|l|}
\hline Responses & $\begin{array}{l}\text { Q8: Does mass media use distinguished sports persons to } \\
\text { encourage others to participate in sport? }\end{array}$ & Percentage \\
\hline $\begin{array}{l}\text { Yes } \\
\mathrm{N}(\%)\end{array}$ & 808 & $80.72 \%$ \\
\hline $\begin{array}{l}\text { Sometimes } \\
\mathrm{N}(\%)\end{array}$ & 157 & $15.68 \%$ \\
\hline $\begin{array}{l}\mathrm{No} \\
\mathrm{N}(\%)\end{array}$ & 36 & $3.6 \%$ \\
\hline
\end{tabular}

From the above question regarding the Mass Media Use Distinguished Sports Persons to Encourage Others to Participate in Sport, it is observed that:

$80.72 \%$ Say Yes to The mass media use distinguished sports persons to encourage others to participate in sport.

$15.68 \%$ Say Sometime mass media use distinguished sports persons to encourage others to participate in sport.

3.6\% Say No mass media use distinguished sports persons to encourage others to participate in sport. 


\subsection{Tables}

Mass Media Have a Role to Encourage Participation in Sports Activities in Order to Improve Health.

\begin{tabular}{|l|l|l|}
\hline Responses & $\begin{array}{l}\text { Q9: Do mass media have a role to encourage } \\
\text { participation in sports activities in order to improve } \\
\text { health? }\end{array}$ & Percentage \\
\hline $\begin{array}{l}\text { Yes } \\
\mathrm{N}(\%)\end{array}$ & 824 & $82.32 \%$ \\
\hline $\begin{array}{l}\text { Sometimes } \\
\mathrm{N}(\%)\end{array}$ & 158 & $15.78 \%$ \\
\hline $\begin{array}{l}\mathrm{No} \\
\mathrm{N}(\%)\end{array}$ & 19 & $1.9 \%$ \\
\hline
\end{tabular}

From the above question regarding the Mass Media Have a Role to Encourage Participation in Sports Activities in Order to Improve Health, it is observed that:

82.32\% Say Yes To The mass media have a role to encourage participation in sports activities in order to improve health.

$15.78 \%$ Say Some time mass media have a role to encourage participation in sports activities in order to improve health.

$1.9 \%$ Say No mass media have a role to encourage participation in sports activities in order to improve health.

Significance of the Study proposed were: The results may find helpful to the players to make up their minds for the fame and defame thorough the media; The results may also find helpful to the coaches to encourage their player during their defeat and defame in media; The results may find helpful to the association/ federation personnel to keep up pace and also provide ample facilities and development through media.

\section{CONCLUSIONS}

1. From the above question regarding the Participate in Physical Activities Regularly, it is observed that: $84.32 \%$ Say Yes, $14.90 \%$ Say Sometime and 1.6\% Say No Participate in Physical Activities Regularly.

2. From the above question regarding the Mass Media Provide You with Adequate Information about Sport Benefits it is observed that: $86.91 \%$ Say Yes, $12.39 \%$ Say Sometime and $0.7 \%$ Say No mass media provide you with adequate information about sport benefits. 
3. From the above question regarding the Mass Media Play a Role in The Dissemination of Sport Benefits for Good Health, It is observed that: 67.63\%Say Yes, 31.37\%Say Sometime and 1.2\% Say No mass media play a role in the dissemination of sport benefits for good health.

4. From the above question regarding the Mass Media Show an Interest in Health Benefits of Sport, it is observed that: $82.32 \%$ Say Yes, $15.78 \%$ Say Sometime and $1.9 \%$ Say No Mass Media Show an Interest in Health Benefits of Sport.

5. From the above question regarding the Mass Media Encourage and Cover Sport Activities for Good Health, it is observed that: $85.31 \%$ Say Yes, $12.99 \%$ Say Sometime and $1.7 \%$ Say No mass media encourage and cover sport activities for good health.

6. From the above question regarding the Mass Media Have an Influence on the Public to Participate in Sport Activities, it is observed that: $86.91 \%$ Say Yes, $12.39 \%$ Say Sometime and $0.7 \%$ Say No mass media have an influence on the public to participate in sport activities.

7. From the above question regarding the Mass Media Your Only Source to Get Information About Sports, it is observed that: $67.43 \%$ Say Yes, $31.37 \%$ Say Sometime and $1.2 \%$ Say No mass media your only source to get information about sports.

8. From the above question regarding the Mass Media Use Distinguished Sports Persons to Encourage Others to Participate in Sport, it is observed that: $80.72 \%$ Say Yes, $15.68 \%$ Say Sometime and $3.6 \%$ Say No mass media use distinguished sports persons to encourage others to participate in sport.

9. From the above question regarding the Mass Media Have a Role to Encourage Participation in Sports Activities in Order to Improve Health, it is observed that: $82.32 \%$ Say Yes, $15.78 \%$ Say Sometime and $1.9 \%$ Say No mass media have a role to encourage participation in sports activities in order to improve health.

\section{Bibliography}

[1]. Mehta, N., 2007. The great Indian Willow Trick: Cricket, nationalism and India's TV news revolution, 1998-2005. The International Journal of the History of Sport, 24(9), pp.1187-1199.

[2]. Mohibullah Khan Marwat1,et al. (2014) Asian Journal of Social Sciences \& Humanities Vol. 3(3) August 2014 Mass Media and Promotion of Sport (Historical Perspectives), Iffat Bi Bi5.

[3]. Nazemi, Y and Khoshemehr, A. H. (2012). Media and Impact on Sport. International Journal of Sport Studies, 624-630. 
[4].Tuggle, C., \& Huffman, S. (2001). Live Reporting in Television News: Breaking News or Black Holes? Journal of Broadcasting \& Electronic Media, 45 (2), 335-344.

[5].Van Heerden, C., et al. (2004). Media Exposure and Sponsor Recall: Cricket World Cup 2003. South African Journal for Research in Sport, Physical Education and Recreation, 26 (2), 131 140. 